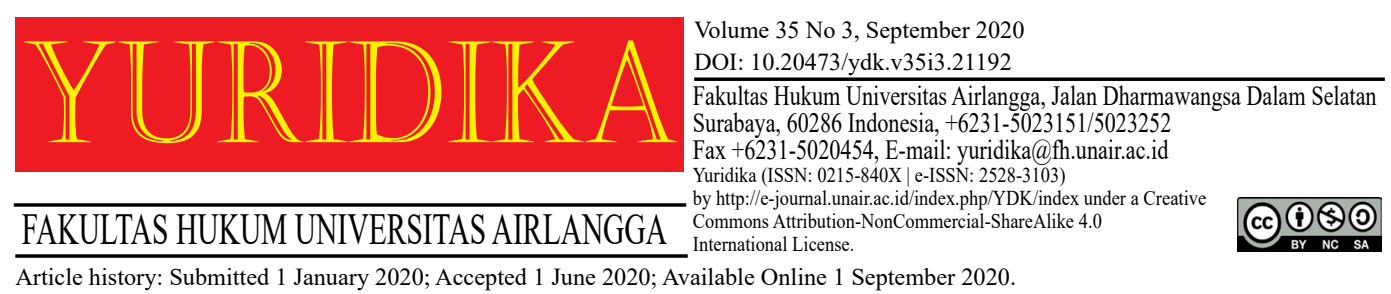

\title{
Tackling the Problem of Crops Supply Chain in Indonesia using Internet of Things Based on Law of the Farmers
}

\author{
Intan Inayatun Soeparna \\ intan@fh.unair.ac.id \\ Universitas Airlangga
}

\begin{abstract}
One of the agricultural problems in Indonesia is the crops supply chain that hampers the ability of the farmers to achieve better income from their farming activities. Although the government has issued the Law of the Farmer No 19 the year 2013 to protect and empower the farmer, the problem is still prevalent. It leads to a question of how to implement the law to tackle the problem of the crops supply chain. The study explains that the government has issued an Economy Digital Policy to create electronic commerce in agribusiness (E-Agribusiness) for farmers and to solve their agribusiness problem. However, the use of electronic agribusiness is not yet ample to solve the problem of the crops supply chain. The solution is a suggestion to apply Internet of Things which is using RFID technology to solve the problem of crops supply chain and distribution in E- Agribusiness. The methodology of the study is the normative approach and literature review.
\end{abstract}

Keywords: Blockchain; Crop; Supply Chain; Farmer Law.

\section{Introduction}

According to Food and Agriculture Organisation (FAO), food security is attained when all people, at all times, have physical and economic access to sufficient, safe and nutritious food to meet their dietary needs and food preferences to lead a healthy and active life. ${ }^{1}$ The agricultural policy in Indonesia adopts the FAO principle of food security in correlation with the development of rural and traditional agriculture activities. According to Indonesian food law, food security is the fulfilment of food for all individual reflected by food availability in terms of sufficient both in quantity and quality, safe, diverse, nutritious, prevalent

1 FAO, 'The State of Food Insecurity in the World 2001' (FAO, 2001) <http://www.fao.org/ docrep/003/y1500e/y1500e00.htm> accessed 24 September 2017. 
and affordable as well as not conflicting with religion, belief and culture, to live healthy, active and productive. ${ }^{2}$ There are four essential aspects related to food security. The first is the availability of sufficient quantities of food in an appropriate quality that is supplied through domestic production or import. The second is the accessibility of food in which every individual can access adequate resources both physically and economically. The third is the stability of the accessible food for a population, household or individual. And the fourth is the utilisation of food through adequate diet, sanitation, water and healthcare to reach a state of nutritional well-being. ${ }^{3}$

The Government of Indonesia is necessary to improve the domestic agricultural management system to implement the objectives of food security. It is due to that Indonesia is an agricultural country where agriculture is an economic backbone of the nations. Agriculture is an important sector because it involves food and employment sectors. Almost half of the population is directly or indirectly working in the food and agriculture sectors, either the small scale farming or big agriculture industry. In 2017, almost 39, 68 million Indonesian is working in the agriculture sector or approximately 31,86 per cent from 124, 54 million workers in Indonesia, ${ }^{4}$ most of them are small scale farmers. The small scale farming is usually owned by a family with a small amount of capital and using traditional farming management.

Nevertheless, the farmers in Indonesia often lack financial support and production guidance of professional and technical experts. They also lack the knowledge for modern agricultural technology that affects their products. Most

\footnotetext{
2 Iqbal Rafani, 'The Law No 18/2012 Governing Food Security in Indonesia, FFTC Agriculture Policy Platform' (Food and Fertilizer Technology Center for the Asian and Pacific Region, 2014) <http://ap.fftc.agnet.org/ap_db.php?id=182> accessed 15 December 2018.

3 FAO, "Food Security", Policy Brief: FAO's Agriculture and Development Economics Division (ESA) with Support from the FAO Netherlands Partnership Program (FNPP) and the EC-FAO Food Security Program (Issue 2)' (FAO, 2006) < http://www.fao.org/forestry/13128-0e6f36f27e0091055bec28ebe830f46b3.pdf> accessed 4 March 2018.

4 Badan Pusat Statistik, 'Data Jumlah Petani Berdasarkan Subsektor Dan Jenis Kelamin' (Badan Pusat Statistik, 2017) < http://data.go.id/dataset/data-jumlah-petani-berdasarkan-subsektor-dan-jenis-kelamin $>$ accessed 21 January 2018.
} 
of the farmers in Indonesia encounter problems related to the availability of the agricultural product, supply chain and distribution management as follows: ${ }^{5}$

1) The availability of the agricultural product is still seasonal

Until today, Indonesian farmers are still using traditional farming techniques to produce their crops. Their conventional farming technologies affect the quality of agriculture commodities, and it ultimately affects the stock of seasonal plants. This condition creates the instability of the market demands. When in the period of harvest, the commodities will be abundantly available and resulting in the decreasing of the price in the market. On the other hand, after the harvest period is over, the availability of the crops will be limited that is resulting in the increasing of the price in the market. The instability of the availability of the crops then creates a problem for farmers either to sell their products or to receive a stable income. In addition to this, the farmers also are unable to provide export demands which make them lag behind agricultural producers with the same commodities from other countries.

2) The long and costly agricultural product supply chain

The lengthy crops supply chain will consume an expensive operational cost for the farmers. The expensive operational cost will then affects the benefit from the sale of the crops. It becomes a problem for farmers. The issues relating to crops supply chain, interalia; 1) the uncertainty quality of product; 2) the lack of quality supervision along the chain; 3) the lack of market information; 4) the lack of transparency in pricing; and 5) there is no ability to tracking and tracing of the crops. The biggest problem in the crops supply chain in Indonesia is the lack of transparency of pricing. Farmers or producers are mostly struggling to sell their produce at a decent cost. However, the middleman takes up its role resulting in the price of the crop is higher in the market than the original price from the farmers. For example, in 2017, most of the onion farmers sold their products up to Rp $10-15.000 / \mathrm{kg}$ (approximately a dollar $/ \mathrm{kg}$ ) and the middleman sold their products up to $100 \%$ from the original price.

\footnotetext{
5 Info agri bisnis, '3 Kendala Pemasaran Produk Pertanian Yang Sering Anda Temui' (info agri bisnis, 2017) < http://www.infoagribisnis.com/2017/05/pemasaran-produk-pertanian/> accessed 21 January 2018.
} 
It means that the farmers only enjoy the benefit of their products for $10 \%-20 \%$ from the market price. ${ }^{6}$ It shows that the pricing mechanism of onion was not transparent and depending on the power of middleman in the supply chain. Therefore, the crops supply chains in most developing countries, including Indonesia, are inefficient due to information asymmetry. The result is that the farmers do not receive their due share, even though they are an essential part of the chain (the producers).

3) The lack of market information for the farmers

The lack of market information is a problem in distribution management, especially for small scale farmers in a remote area, due to the lack of knowledge and capability to analyse the market. Most of these farmers do not equip with information regarding potential consumers. They also lack an understanding of how to obtain the information of the potential consumers. This problem creates the difficulty to maximise the distribution efforts.

Those problems above directly affect the farmers to achieve economy of scale, due to the issues that create huge transactional costs from production to the end consumers. It then affects the income of the farmers especially for the farmers who work in a small scale farming system using traditional farming technology on less than 0, 3 hectare of land. The farmers gain income in the range of Rp. 3, 98 million - 1 million per month or approximately up to 47, 76 million Rupiah per year. ${ }^{7}$ They usually have a lower income than the average worker in other sectors. The lower-income then affects the welfare of the farmers.

The most affecting problem is the agricultural product supply chain management. The impact of lengthy and costly supply chain management is not only reducing the income of the farmers but also affecting the stability of food and agricultural distribution, and hence it will create the problem for the population to access the food for their daily life.

\footnotetext{
6 Hortikultura, 'Kementerian Pertanian Indoneisia 2017' (Hortikultura, 2017) <http://hortikultura.pertanian.go.id/?p=717> accessed 1 June 2018.

7 Mukhamad Kurniawan, 'Swasembada Minus Lahan' (pressreader, 2017) <https://www. pressreader.com/indonesia/kompas/20170711/281956017821362> accessed 21 January 2018.
} 
Speaking about the welfare of the farmers, the Government of Indonesia has given the best concern regarding of it, by issuing Law No 19 the year 2013 on the Protection and Empowerment of the Farmer (the Law of the Farmer). The primary objective of the Law of the Farmer is to improve the welfare of the farmer in Indonesia. However, there is a gap between the law and the condition of the farmer today that leads to a question of how to implement the law to tackle the problem of the agricultural supply chain?. The law of the farmer introduces an integrated and suitable arrangement to achieve the optimum targets of the protection and empowerment of the farmer. It enshrines in its objectives as follow: ${ }^{8}$

1. Realising the sovereignty and independence of the farmers to improve their welfare, good quality and better living;

2. Providing better agricultural infrastructures and facilities to develop a farming system;

3. Providing insurance for farming;

4. Protecting farmers from price fluctuation, high-cost economy practice and crop failure;

5. Increasing the capability and capacity of the farmers as well as farmer organisation; and

6. Developing agricultural finance institutions.

These objectives are defined in the purpose to protect and to empower the farmer. The purpose of protecting the farmer refers to all necessary efforts to assist the farmers to deal with the problems relate to infrastructures and production facilities, business certainty, price risk, crop failure, high-cost economic practice and climate change. Meanwhile, the purpose of empowering the farmer refers to all necessary efforts to improve the capability of the farmer to implement better farming through education and training. The government set up strategies to achieve the purpose of the protection of the farmer as follow: ${ }^{9}$

1. Issuing the provision of agricultural infrastructures and facilities;

2. Promotion business certainty;

3. Setting up the appropriate price for agricultural commodities;

4. The elimination of high-cost economy practices;

5. Releasing the provisions to compensate the farmer for the crop failure due to extraordinary events;

6. Issuing the regulation of early warning system due to exceptional circumstances;

8 Law No. 19 of 2013 concerning Empowerment and Protection of Farmers.

9 ibid. 
7. Tackling the impact of climate change;

8. Developing agricultural insurance;

The government implements the strategies to protect the farmers along with the plan to empower the farmers:

1. Education and training;

2. Counselling and mentoring development of marketing system and facilities for agricultural products;

3. Consolidation and assurance of agricultural land;

4. Providing easy access to science, technology and information, and;

5. Strengthening the farmer organisation

One of the strategies to empower farmers is to provide easy access to science, technology and information. This strategy aims to empower the farmer with knowledge and to support the farmers to solve the problem of the crops supply chain, marketing and the distribution to the market.

Information and communication technology (ICT) is one of the best options to implement the strategy to empower the farmer under the Law of the Farmer. There are two systems in ICT that can help the farmers to achieve benefit from their crops supply chain, marketing and distribution. First is electronic commerce in agribusiness (E-Agribusiness) and second, is the application of the internet of things (IoT) to support the system of supply chain and distribution.

This research is analysing the possible technology to solve the problem in crops supply chain and distribution management of agribusiness in Indonesia. It begins with the review of technology involved in the crops supply chain and analysis of the Law No 19 the year 2013 Article 67 regarding the obligation of the government to provide easy access for the farmers to the knowledge, science and technology to improve the agricultural system and agribusiness. Article 67 is implemented through the application of ICT to tackle the problem of crops supply chain and distribution. The method of this research is a literature review of the type of IoT. The reason to imply IoT is that this technology can solve the problem of crops supplies chain and distribution. 


\section{Technology Involves in Crops Supply Chain and Distribution}

Electronic commerce (E-commerce) is any form of economic activity conducted through electronic connections. The bandwidth of electronic commerce spans from electronic markets to electronic hierarchies which incorporates electronically to support entrepreneurial networks. ${ }^{10}$ The interface is interconnected to perform entrepreneurial activities or to complete a particular target. The information received from the interconnected network is processed data that has meaning and useful for the user. ${ }^{11}$ E-commerce has been used for many decades by retailers and consumers in many countries, including Indonesia. Some major leading countries have developed and transformed E-commerce to be more convenient and efficient by using the Internet of Things (IoT). When it comes to technology, IoT is the latest buzz because the IoT is enabling devices to exchange data with each other more efficient that influences the benefit of the users. IoT is expected to have more impact on E-commerce business.

IoT is recognised as an interconnected object through the internet, with the concept that every object is connected through a unique identifier that can transfer data through the network without human interaction. ${ }^{12}$ The idea of IoT in agriculture can be used in a different domain, such as precision agriculture, product supply management, smart grid, environment monitoring and cloud computing; ${ }^{13}$ it is known as smart farming. It can be implied from upstream to a downstream agricultural production system. Smart farming is the development of agricultural technology that is using information technology in the cycle of farming management using cyber-physical. New technology such as IoT and Cloud Computing has

${ }^{10}$ Rolf T. Wigand, Electronic Commerce: Definition, Theory and Context (The Information Society 1997).[1-16].

${ }^{11}$ Ujang Maman and Yuni Sugiarti, 'The Need of Agribusiness E-Commerce to Support Staple Food Self-Sufficient: The Experience from West Java' (2016) 11 International Journal of Applied Agriculture Research.[115-128].

12 Sarita Agrawal and Manik Lal Das, 'Internet of Things-A Paradigm Shift of Future Internet Applications', Engineering (NUiCONE) (Nirma University International Conference 2011). [1-7].

${ }^{13}$ Raheela Shahzadi,[et.,al.] 'Internet of Things Based Expert System for Smart Agriculture' (2016) 7 International Journal of Advanced Computer Science and Applications.[11-26]. 
influenced the development of agricultural technology, and it is using a robot or artificial intelligent in agriculture. ${ }^{14}$ Smart farming also includes the supply chain of agricultural product using IoT.

\section{The Implementation of Article 67 of the Law of the Farmer}

Under Article 67 of the Law of the Farmer, the government should provide easy access to knowledge, technology and information for the farmers to achieve a standard of the quality of the agricultural commodities. Access to technology includes: ${ }^{15}$

1. Dissemination of knowledge and technology;

2. Transfer of technology;

3. Providing the facilities for farmers to access the ICT or other knowledge related to agriculture.

According to Article 67, the information regarding technology should be accurate, punctual, fast and easy to access by farmers, the agricultural industry and society. It means that the technology should be visible and flexible to accommodate the need of the farmers to overcome the problems of farm activities. The most relevant technology is the technology to aid the supply chain and distribution management in agribusiness. It is necessary to equip the farmers with the technology that helps them to overcome the problem of lengthy and costly supply chain and to provide better market information.

In 2016, the government issued the program of Economic Digital called "Action Synergy Program" to aid the farmers to solve the problem of the crops supply chain and to tackle the issue of the middleman. This program is introducing easy access for farmers to interact with the end consumers using digital service in the form of electronic commerce to sell the crops. ${ }^{16}$ Through this program, the government is supporting the digital application for farmers to sell their products

\footnotetext{
${ }^{14}$ Sjaak Wolfert, 'Big Data in Smart Farming' (2017) 153 Agricultural Systems.[69-80].

${ }^{15}$ Law No. 19 of 2013 concerning Empowerment and Protection of Farmers, Article 67.

16 Kementrian Keuangan, 'President Luncurkan Program Sinergi Aksi Untuk Ekonomi Rakyat' (Kementrian Keuangan Republik Indonesia, 2016) < https://www.kemenkeu.go.id/publikasi/berita/presiden-luncurkan-program-sinergi-aksi-untuk-ekonomi-rakyat/> accessed 12 June 2018.
} 
directly to the consumers using E-commerce. Both farmers and consumers can use a web browser where the farmers can upload the information on the products, and the consumers can purchase the product directly.

There are several E-commerce applications start-ups for agribusiness in Indonesia such as www.limakilo.id, Pantau Harga and TaniHub. These applications are integrating the electronic commerce components such as website, logistics, online advertisement, and payment gateway as well as market analysis in agribusiness. The purpose of E-commerce for agribusiness in Indonesia is to cut the middleman on the basis that the direct sale of crops to the consumer will give fair pricing of the products. TaniHub has the concept to help the farmer to connect with consumers directly, cutting out many intermediaries who drive prices up for consumers and keep farmers' profit margins are low. Pantau Harga is an app that provides producers and consumers with a real-time commodity price. ${ }^{17}$ In addition to this, the E-commerce for agribusiness can strengthen the position of the farmers which it offers excellent opportunities for collaboration and joining forces by farmers,${ }^{18}$ for example, $w w w$. limakilo.id provides cooperation of farmers for the specific product to give a certain amount of crops for retailers or consumers.

\section{Electronic Agribusiness in Indonesia: A Challenge}

Electronic Agribusiness (E-Agribusiness) is a part of Electronic Agriculture (E-Agriculture) which is defined as "the application of modern information and communication technology (ICT) to agriculture and rural development with the goal to improve human livelihood by reducing poverty and hunger among the rural communities". ${ }^{19}$ FAO defines E-Agriculture as "an emerging field in the intersection

\footnotetext{
${ }^{17}$ Nadine Freischlad, 'Freischlad, N., Indonesia Wants Farmers and Fishermen to Join the e-Commerce Revolution' (TECHINASIA, 2016) < https://www.techinasia.com/indonesia-ecommerce-conversation-shifts-agriculture-fisheries $>$ accessed 18 June 2018.

18 Dariusz Strzębicki, 'The Development of Electronic Commerce in Agribusiness - The Polish Example' (2015) 23 Procedia Economics and Finance.[1314-1320].

19 Blessing M. Maumbe, 'The Development of E-Agriculture in Sub Saharan Africa: Key Considerations, Challenge and Policy Implementation' in Blessing M. Maumbe (ed), E-Agriculture and E-Government for Global Policy Development: Implications and Future Directions (Hershey Information Science Reference 2010).[75].
} 
of agricultural development and entrepreneurship, referring to agricultural services, technology dissemination, and information delivered or enhanced through the internet and related technologies. More specifically, it involves the conceptual, design, development, evaluation and application of new ways to use existing or emerging ICT". ${ }^{20}$ Many agribusiness organisations have capitalised on many advantages of electronic commerce to improve the marketing of their products. The technology of information embodied in E-commerce is a platform to provide sharing information among farmers (producers), retailers and consumers. The modern infrastructure of information technology integrates all types of information and resources through technical facilities in advanced networks and communication tools. ${ }^{21} \mathrm{E}$-commerce is increasing benefit for agricultural sectors because of the high reliance on accurate and punctual information in a considerable physical distance between farmers and consumers. Many benefits of E-commerce in agribusiness are: 1) providing the possibilities of cost reduction and enhancement along the agriculture or food supply chain, 2) automation capacity that substantially reduces transaction and procurement cost, 3) improving efficiency by reducing inventory levels, transportation costs, order and delivery time, and 4) more transparent and competitive than physical market. ${ }^{22}$

However, the application of E-Agribusiness in Indonesia is facing some challenges, for example, 1) the most of the farmers lack the knowledge and necessary information for the use of electronic commerce and internet networks due to low education background of the farmers. 2) The lack of infrastructure on the internet. 3) The high price of the software in E-agribusiness. 4) The characteristic of agriculture product is seasonal with the high volume but the low value with

20 ibid

${ }^{21}$ Zhang Chunhua and Zhang Bo, 'Bottleneck Problems in China's E-Agr Development', The 2nd Conference on Environmental Science and Information Application Technology (2010) $<$ https://ieexplore.ieee.org/abstract/document/5568741>.[628-631].

22 Shanmuga Vivekananda Nadarajan and Roslan Ismail, 'E-Commerce Framework to Improve Rural Agriculture Sector in Cambodia', International Conference on E-business, Management and Economics IPEDR Vol.25 (IACSIT Press 2011).[287-291]. 
a different standard in each country. ${ }^{23}$ Moreover, E-agribusiness in Indonesia mostly is using conventional electronic commerce in which the application still comprises some problems. The prominent problem in E-agribusiness is supply chain management, especially in the logistics and distribution system. It is an integral part of E-commerce operation and plays a vital role in E-commerce of agribusiness. The agricultural supply chain in agribusiness encompasses the flow of products, knowledge and information between agricultural stakeholders and consumers. ${ }^{24}$ The whole supply chain process for E-Agribusiness must be smooth and effective.

E-Agribusiness is similar to other E-commerce for business where the internet is connecting customers or mobile devices with online and service providers through an E-commerce website or mobile applications. The retailers or distributors are mostly acting as intermediaries between producers and consumers. For example, Tani Hub is an only intermediary application that is connecting farmers or producers to consumers. However, the retail or intermediary is seldom joining other things such as products (in agriculture is the crop or food) that are purchased by consumers. The online retailer is also hard to collect information regarding the quality of the product during transport or whether the product is satisfied with the consumers. Especially for perishable good like fresh agricultural products, the conventional E-agribusiness mostly lack real-time information, disperse of production and the disequilibrium of market forces. ${ }^{25}$ The lack of real-time information leads to misplace information among the producers, retailers and consumers. The absence of real-time data also creates a long-time product circulation and distribution that hinders to the upstream enterprise to know the sales and other downstream enterprises to

\footnotetext{
${ }^{23}$ Soekartawi, 'E-Agribisnis: Teori Dan Aplikasinya', Seminar Nasional Aplikasi Teknologi Informasi (2007).[19-25].

${ }^{24}$ Anja-Tatjana Braun, 'Farming in the Era of Industry 4.0' (2018) 72 Procedia CIRP $<$ https:// www.sciencedirect.com/science/article/pii/S2212827118303342>.[979-984].

${ }^{25}$ Liheng Zhang, 'Application of IOT in the Supply Chain of the Fresh Agricultural Products', International Conference on Communications, Information Management and Network Security $(2016)<\mathrm{https}$ //www.atlantis-press.com/proceedings/cimns-16/25862461>.[201-204].
} 
know the product situation. The disperse situation of production also becomes a problem in E-Agribusiness where producers or farmers scattered around the country as well as consumers who will find difficulty to grasp specific information on the market supply and demand. ${ }^{26}$

To tackle the problem of supply chain and distribution in E-Agribusiness, some scholars suggest applying the Internet of Things (IoT). ${ }^{27}$ The application of IoT to supply chain management would wipe off the "bullwhip effect", and the real-time product information would help the E-Agribusiness stakeholders to track product during the supply chain process. ${ }^{28}$

\section{The Application of IoT in Crops Supply Chain}

Internet of Things is a part of the development of ICT today. The concept is basically to connect numerous things or objects such as Radio Frequency Identification (RFID) tags, sensors, actuators, mobile phones or others through the internet. The objects have a unique address to interact and co-operate, to compile, process and distribute using wireless and non-wireless communications systems with each other. ${ }^{29}$ The RFID technology is integrating the data, distribution and safety of quality in the agricultural supply chain effectively, ${ }^{30}$ which can develop electronic commerce in agribusiness. Moreover, the IoT can enhance the application of electronic commerce in agribusiness, for example, in the core of supply chain management in which logistics is part of it. IoT thus can support the intelligent logistics to develop better electronic commerce in agribusiness, where the whole

26 ibid.

27 Du Jin, 'Application of "Internet of Things" in Electronic Commerce' (2012) 6 International Journal of Digital Content Technology and its Applications.[222-230].; see also Xiaohui Wang and Nannan Liu, 'The Application of the Internet of Things in Agricultural Means of Production Supply Chain Management' (2014) 6 Journal of Chemical and Pharmaceutical Research. [2304-2310].; see also Liheng Zhang (n 26).[201-204].; see also Xiaomin Xu, 'IOT Technology Research in E-Commerce' (2014) 13 Information Technology Journal <https://scialert.net/fulltex$\mathrm{t} /$ ?doi=itj.2014.2552.2559>.[2552-2559].

${ }_{28} \mathrm{Du}$ Jin (n 28).

${ }^{29}$ Md Nazmus Sakib Miazi,[et.,al.], 'Enabling The Internet of Things in Developing Countries: Opportunities and Challenges', 5th International Conference on Informatics, Electronics and Vision (ICIEV) (https://ieeexplore.ieee.org/document/7760066 2016).

${ }^{30}$ Xiaohui Wang and Nannan Liu (n 28). Supra Note 29, [2304-2310]. 
process of the goods delivery, supplies, transportation base on the instruction of corporate computer systems.

IoT can also streamline the supply chain process from one stage to the next step without interruption. It allows E-Agribusiness stakeholders to track products from downstream to upstream. The GPS and RFID technologies aid the E-Agribusiness stakeholders to track product in the supply chain process such as transit and delivery using key information about the location to prevent shipments from being misplaced or lost and to estimate the delivery times.

$\mathrm{Xu}$ analysed three leading roles of the IoT in the intelligent supply chain system, as follow: ${ }^{31}$

a) Management tools smart upgrades

This smart management tool is the coordination between computer technologies, barcode, RFID in the logistics and supply chain in which the function is to reduce the costs of the logistics chain. In agribusiness, the accurate and precise time for the management of logistics is necessary since it is related to the perishable good. This tool is creating fast and reliable information on the product along the distribution chain.

b) Transport intelligent upgrades

E-commerce in agribusiness will not fall apart from the reliable transportation system. In the smart transport, GPS and networking technology could be used to realise the visualised tracking management as a part of the process, accurately predict the arrival time of goods, shorten delivery time and improve efficiency. In the agribusiness where the agricultural product often has an expiry period, intelligent transport can reduce the possibility of uncertainty delivery timing.

c) Product safety upgrades

RIFD technology can create a traceability network system for an agricultural product. The intelligent product traceability system provides reliable cargo logistics support for agriculture and food safety. RFID tags are acting as enhanced barcodes

${ }^{31}$ Xiaomin Xu (n 28). Supra Note 29.[2552-2559] 
that is enable the tracing and tracking an agricultural product during the supply chain or distribution. It combines more than one sensor to enrich the information of product status whenever this is recorded..$^{32}$

\section{The Challenge of Using IoT in Crops Supply Chain in Indonesia}

Although IoT in E-agribusiness will ensure the process of supply chain and distribution of product to be more efficient, traceable, transparent and accessible for E-Agribusiness stakeholders that may increase the income for farmers, IoT may bring some challenges, especially in Indonesia. It is similar to the implementation of electronic commerce in agribusiness; Indonesia is facing some problems to apply IoT in E-Agribusiness. These challenges are as follows:

\section{1) Security Issues}

The prominent threat of IoT is a security issue where the system is vulnerable to computer attacks, such as DDOS, malware and other cybersecurity issues. The method of IoT is a collaboration among all participating nodes, sensors and other wireless devices and items that connected automatically without a fixed infrastructure. This method will be vulnerable from the interception of non-trustworthy networks, where the data may be stolen or altered without authorisation. ${ }^{33}$ Cybersecurity is another problem to solve in Indonesia because it is obliged coordination between technical solution and regulation.

2) Data Privacy

The IoT represents taking the data collection, storage and analysis mechanism to a larger scale that without data privacy protection will create a challenge for users. Indonesia itself does not have a data protection policy which will create a

\footnotetext{
${ }^{32}$ Mirjana Maksimović and Vladimir Vujovic, 'A Low-Cost Internet of Things Solution for Traceability and Monitoring Food Safety during Transportation', The 7th international conference on information and communication technologies in Agriculture, Food and Environment (HAICTA) (2015).[423-428].

33 Chin-Ling,[et.,al.] 'Based on Mobile RFID Device to Design a Secure Mutual Authentication Scheme for Market Application', International Conference on Broadband, Wireless Computing, Communication and Applications (2010) <https://ieeexplore.ieee.org/document/5633012>. [423-428].
} 
vulnerable situation for IoT user.

3) The complexity of the devices, people, interactions and interfaces are creating more risk for data security

4) The expensive of the device

The primary IoT devices and software are costly, especially for the farmers in Indonesia.

5) Human resources

The lack of human resources who experts in IoT also a challenge for IoT in E-agribusiness in Indonesia

\section{Conclusions}

This research concludes that the farmers often encounter the problem in agricultural supply chain and distribution where the traditional mechanism of supply chain and distribution is costly and time-consuming. The government hence is supporting the farmers to easy access to technology by providing the program on the digital application in which can solve the problem of agricultural supply chain and distribution.

The farmers can use ICT application in the form of E-commerce which also can tackle the lack of transparency in pricing because the integration system of electronic commerce pursues the transparency of pricing between the farmers and the consumers. The result of this application is that the farmers can sell the crops directly to consumers without involving the middleman. Moreover, the application of ICT through IoT can tackle the problem of logistics and distribution in E-agribusiness by using the IoT intelligent logistic. This IoT is then able to address the issue of the long chain of distribution. The result is that the IoT in smart logistics is also solving the problem of quality of the product along the chain by using RIFD tag and barcodes and it also helps the farmers to trace and to track the crops along the chain of distribution. The IoT is creating fast, timely and accurate information of the product to sell.

The success of the application of the ICT in agribusiness, both are using the digital application in E-Agribusiness and IoT, is following Article 67 the Law of 
the Farmers. Under this article, the technology should assist the farmer in obtaining the information accurately, fast and easy. As a result of the use of technology, the farmer can conduct better agribusiness to increase their income and to improve their welfare according to the objective of the Law of the Farmer.

However, there are still many challenges regarding the implementation of both E-agribusiness and IoT. The government and E-Agribusiness stakeholders can solve the problem by increasing the awareness of technical cybersecurity, establishing legal environment such as data protection policy and providing a reliable and suitable condition for investment in the ICT sectors.

\section{Bibliography}

Anja-Tatjana Braun, 'Farming in the Era of Industry 4.0' (2018) 72 Procedia CIRP $<$ https://www.sciencedirect.com/science/article/pii/S2212827118303342>.

Badan Pusat Statistik, 'Data Jumlah Petani Berdasarkan Subsektor Dan Jenis Kelamin'(Badan Pusat Statistik, 2017) $<$ http://data.go.id/dataset/data-jumlahpetani-berdasarkan-subsektor-dan-jenis-kelamin> accessed 21 January 2018.

Blessing M. Maumbe, 'The Development of E-Agriculture in Sub Saharan Africa: Key Considerations, Challenge and Policy Implementation' in Blessing M. Maumbe (ed), E-Agriculture and E-Government for Global Policy Development: Implications and Future Directions (Hershey - Information Science Reference 2010).

Chin-Ling, [et.,al] 'Based on Mobile RFID Device to Design a Secure Mutual Authentication Scheme for Market Application', International Conference on Broadband, Wireless Computing, Communication and Applications (2010) $<$ https://ieeexplore.ieee.org/document/5633012>.

Dariusz Strzębicki, 'The Development of Electronic Commerce in Agribusiness The Polish Example' (2015) 23 Procedia Economics and Finance.

Du Jin, 'Application of "Internet of Things" in Electronic Commerce' (2012) 6 International Journal of Digital Content Technology and its Applications.

FAO, 'The State of Food Insecurity in the World 2001' (FAO, 2001) <http://www. fao.org/docrep/003/y1500e/y1500e00.htm> accessed 24 September 2017.

—, "Food Security", Policy Brief: FAO's Agriculture and Development 
Economics Division (ESA) with Support from the FAO Netherlands Partnership Program (FNPP) and the EC-FAO Food Security Program (Issue 2)' $($ FAO, 2006) <http://www.fao.org/forestry/13128-0e6f36f27e0091055bec 28ebe830f46b3.pdf $>$ accessed 4 March 2018.

Hortikultura, 'Kementerian Pertanian Indoneisia 2017' (Hortikultura, 2017) <http:// hortikultura.pertanian.go.id/?p=717> accessed 1 June 2018 .

Info agri bisnis, ' 3 Kendala Pemasaran Produk Pertanian Yang Sering Anda Temui' (info agri bisnis, 2017) < http://www.infoagribisnis.com/2017/05/pemasaranproduk-pertanian/> accessed 21 January 2018.

Iqbal Rafani, 'The Law No 18/2012 Governing Food Security in Indonesia, FFTC Agriculture Policy Platform' (Food and Fertilizer Technology Center for the Asian and Pacific Region, 2014) <http://ap.fftc.agnet.org/ap_db.php?id=182> accessed 15 December 2018.

Kementrian Keuangan, 'President Luncurkan Program Sinergi Aksi Untuk Ekonomi Rakyat' (Kementrian Keuangan Republik Indonesia, 2016) < https://www. kemenkeu.go.id/publikasi/berita/presiden-luncurkan-program-sinergi-aksiuntuk-ekonomi-rakyat/> accessed 12 June 2018.

Law No. 19 of 2013 concerning Empowerment and Protection of Farmers.

Liheng Zhang, 'Application of IOT in the Supply Chain of the Fresh Agricultural Products', International Conference on Communications, Information Management and Network Security (2016) <https://www.atlantis-press.com/ proceedings/cimns-16/25862461>.

Md Nazmus Sakib Miazi, [et.,al], 'Enabling The Internet of Things in Developing Countries: Opportunities and Challenges', 5th International Conference on Informatics, Electronics and Vision (ICIEV) (https://ieeexplore.ieee.org/ document/7760066 2016).

Mirjana Maksimović and Vladimir Vujovic, 'ALow-Cost Internet of Things Solution for Traceability and Monitoring Food Safety during Transportation', The 7th international conference on information and communication technologies in Agriculture, Food and Environment (HAICTA) (2015).

Mukhamad Kurniawan, 'Swasembada Minus Lahan' (pressreader, 2017) $<$ https:// www.pressreader.com/indonesia/kompas/20170711/281956017821362> accessed 21 January 2018.

Nadine Freischlad, 'Freischlad, N., Indonesia Wants Farmers and Fishermen to Join the e-Commerce Revolution' (TECHINASIA, 2016) <https://www.techinasia. 
com/indonesia-ecommerce-conversation-shifts-agriculture-fisheries $>$ accessed 18 June 2018.

Raheela Shahzadi,[et.,al.], 'Internet of Things Based Expert System for Smart Agriculture' (2016) 7 International Journal of Advanced Computer Science and Applications.

Rolf T. Wigand, Electronic Commerce: Definition, Theory and Context (The Information Society 1997).

Sarita Agrawal and Manik Lal Das, 'Internet of Things-A Paradigm Shift of Future Internet Applications', Engineering (NUiCONE) (Nirma University International Conference 2011).

Shanmuga Vivekananda Nadarajan and Roslan Ismail, 'E-Commerce Framework to Improve Rural Agriculture Sector in Cambodia', International Conference on E-business, Management and Economics IPEDR Vol.25 (IACSIT Press 2011).

Sjaak Wolfert, 'Big Data in Smart Farming' (2017) 153 Agricultural Systems.

Soekartawi, 'E-Agribisnis: Teori Dan Aplikasinya', Seminar Nasional Aplikasi Teknologi Informasi (2007).

Ujang Maman and Yuni Sugiarti, 'The Need of Agribusiness E-Commerce to Support Staple Food Self-Sufficient: The Experience from West Java' (2016) 11 International Journal of Applied Agriculture Research.

Xiaohui Wang and Nannan Liu, 'The Application of the Internet of Things in Agricultural Means of Production Supply Chain Management' (2014) 6 Journal of Chemical and Pharmaceutical Research.

Xiaomin Xu, 'IOT Technology Research in E-Commerce' (2014) 13 Information Technology Journal <https://scialert.net/fulltext/?doi=itj.2014.2552.2559>.

Zhang Chunhuaand ZhangBo, 'Bottleneck ProblemsinChina'sE-AgrDevelopment', The 2nd Conference on Environmental Science and Information Application Technology $(2010)<\mathrm{https}$ //ieeexplore.iee.org/abstract/document/5568741>.

HOW TO CITE: Intan Inayatun Soeparna, 'Tackling the Problem of Crops Supply Chain in Indonesia using Internet of Things Based on Law of the Farmers' (2020) 35 Yuridika. 